ISBN 978-93-84468-86-6

2016 International Research Conference on Social Sciences, Humanities and Interdisciplinary Studies

(RCSSHIS-2016)

Pattaya (Thailand) Dec. 16-17, 2016

\title{
Motivation Factors Affecting the Employees Work Performance at Big Lot Factory Land in Pathumthani Province
}

\author{
Tosaporn mahamud ${ }^{1}$, and Premrudee Nguankratok ${ }^{2}$ \\ tosaporn.mah@kbu.ac.th \\ ${ }^{2}$ Postgraduate School of business administration \\ Kasembundit University, Bangkok
}

\begin{abstract}
The purpose of this study is to determine the important of motivation factors affecting the employees work performance at big lot factory land in Pathumthani Province by using a questionnaire as a tool to study. The results will be used as a guideline to build employees performance motivation and a willingness of personnel to devote its efforts to strengthen the productivity of the company.

Findings revealed that most of respondents were females, age between 31-40 years old, single marital status, bachelor degree graduated, average monthly income between 15,000-20,000 baht, and period of work over 6 years. Recommendations from this study were that administrative officers should encourage freedom between the supervisor, subordinates and co-workers through teamwork activities and independent decision making so that each employee could learn and develop at their full capacity, issue job assignments suitable for their abilities, and set up criteria for career advancement and salary adjustment to match with job responsibilities. Consequently, a willingness of personnel to devote its efforts to strengthen the productivity of the Organization.
\end{abstract}

Keywords: factor, motivation, performance

\section{Introduction}

To be effective in work performance, person has to satisfy with his work and happy with his life. As a result, job duty will be effective and enjoyable, many scholars all over the world have been studied the concept of motivation factors which directly correlated with internal motivation that occurs when perform the duties and satisfy with their outcome of their abilities. If organization response to employees motivation factors, employees will pay attention and works to the full of their capacities effectively. These motivation factors are job completion, job recognition, job description, job ability, and career advancement opportunity.

Motivation is a theoretical construct used to explain behavior. It gives the reasons for people's actions, desires, and needs. Motivation can also be defined as one's direction to behavior, or what causes a person to want to repeat a behavior and vice versa. ${ }^{1}$ A motive is what prompts the person to act in a certain way, or at least develop an inclination for specific behavior. ${ }^{2}$ According to Maehr and Meyer, "Motivation is a word that is part of the popular culture as few other psychological concepts are." ${ }^{3}$

From introduction mentioned above, researcher are interested in studying the important of motivation factors affecting the employees work performance at big lot factory land in Pathumthani Province and results will be a guideline to develop in human resources department policy in order to benefit to all.

\footnotetext{
${ }^{1}$ Ellliot, Andrew J; Covington, Martin. "Approach and Avoidance Motivation". Educational Psychology Review. 13 (2001): 2.

2 Pardee, R. L. (1990). Motivation Theories of Maslow, Herzberg, McGregor \& McClelland. A Literature Review of Selected Theories Dealing with Job Satisfaction and Motivation.

${ }^{3}$ Maehr, Martin L; Mayer, Heather (1997). "Understanding Motivation and Schooling: Where We've Been, Where We Are, and Where We Need to Go". Educational Psychology Review. 9 (44).
} 


\section{The Purpose of the Study}

The purpose of this study is to determine the important of motivation factors affecting the employees work performance at big lot factory land in Pathumthani Province.

\section{Scope of Content}

The purpose of this study is to determine the important of motivation factors affecting e employees work performance at Big Lot Factory Land in Pathumthani according to the theory of Herzberg's two factors theory with the following aspects: Job completion, Job recognition, Job description, Job responsibility, and career advancement opportunity.

\section{Sample Selection}

The samples were 385 employees of Big Lot Factory Land in Pathumthani Province. Study period from January - April 2559.

\section{Data collection Procedure}

The questionnaires were distributed to sample of 385 employees of Big Lot Factory Land in Pathumthani Province. A total of 385 usable questionnaires were returned back to the researcher, yielding a 100 percent response rate and no missing data.

\section{Statistics used in the Sata Analysis}

1. Descriptive statistic is an analysis to find frequency, percentage, mean, standard deviation which describe the personal factors of satisfaction and motivation factors.

2. Inferential statistic is an analysis to test the hypothesis by using t-test, one-way Anova, and regression analysis.

\section{Conceptual Framework of the Study}

From the above study, researcher have used theory of Herzberg's two factors theory as for conceptual framework of the study.

\section{Independent Variables}

\section{Factors of Personal}

1. Gender

2. Age

3. Marital status

4. Level of education

5. Average monthly income

\section{Dependent Variables}

Factors of Motivation

1. Job completion

2. Job recognition

3. Job description

4. Job responsibility

5. Career advancement opportunity 


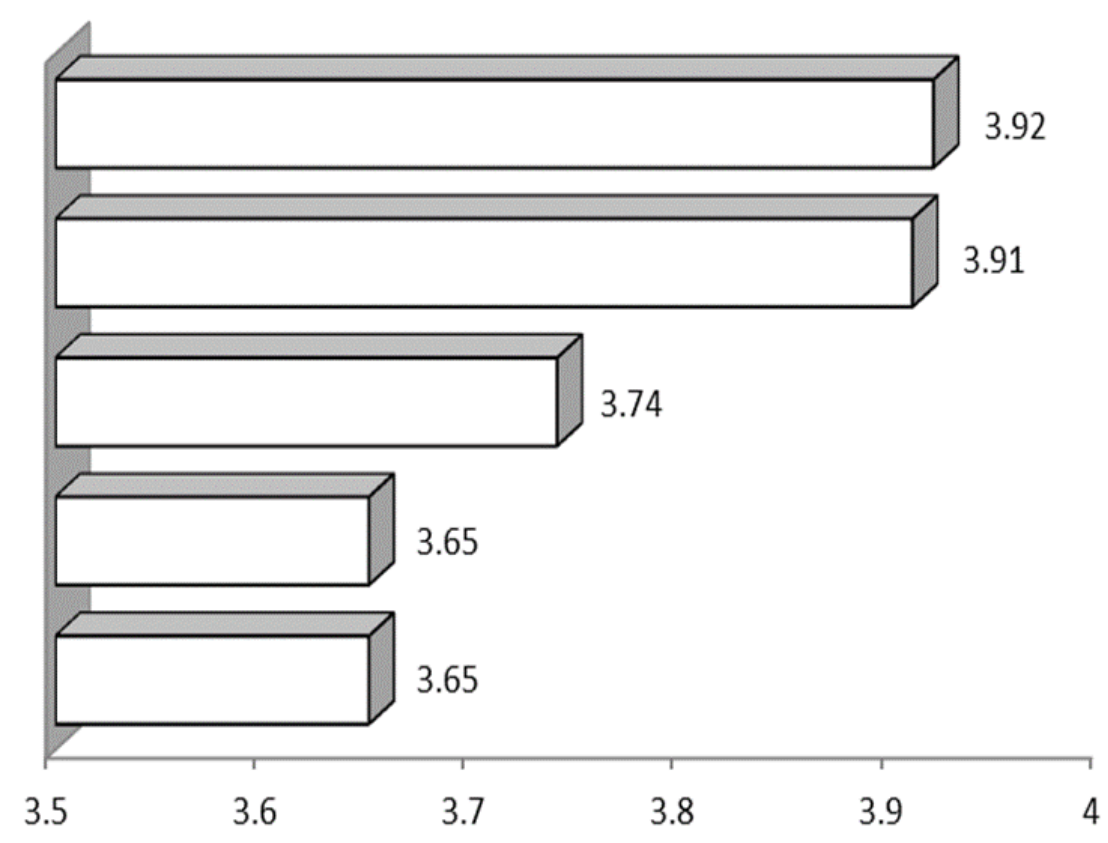

The average picture of opinions of respondents regarding factors of motivation affecting the employees work performance at big lot factory land in Pathumthani Province were at following aspects: job completion aspect $(\bar{x}=3.92)$, work recognition $(\bar{x}=3.91)$, job description $(\bar{x}=3.74)$, career advancement opportunity $(\bar{x}=3.65)$, and Job responsibility $(\bar{x}=3.65)$, respectively.

Factors of personal: The samples were 385 employees of Big Lot Factory Land in Pathumthani Province that most of respondents were females, age between 31-40 years old, single marital status, bachelor degree graduated, average monthly income between 15,000-20,000 baht, and period of work over 6 years.

From the study of the important of motivation factors affecting the employees work performance at big lot factory land in Pathumthani Province which the average picture of the opinions were in high level as following aspects: job completion, job recognition, job description, career advancement opportunity, and job responsibility, respectively.

Job completion aspect revealed that respondents agreed with factor of work motivation which work completed on schedule from the assignment that given by supervisors.

Job recognition aspect revealed that respondents agreed with factor of work motivation, such as independent decision making so that each employee could learn and develop their skills at their full capacity, create relationship among workers and managers, appreciation of employees, and furthermore they would feel they were part of organization.

Job description aspect revealed that respondents agreed with factor of work motivation, such as assign job with challenge and appropriate to skill level, and allow employees to make their own decision.

Job responsibility aspect revealed that respondents agreed with factor of work motivation, such as independent decision making and follow up with their assignment until job accomplishment, and assign duty and responsibility clearly.

Career advancement aspect revealed that respondents agreed with factor of work motivation, such as encourage employees to attend advance coursed for their career advancement path, job rotation, job training for a better position, and job promotion with proper skill.

\section{Recommendation from the Study}

Recommendations from this study were that administrative officers should encourage freedom between the supervisor, subordinates and co-workers through teamwork activities and independent decision making so that each employee could learn and develop at their full capacity, issue job assignments suitable for their abilities, and set up criteria for career advancement and salary adjustment to match with job responsibilities. Consequently, a willingness of personnel to devote its efforts to strengthen the productivity of the Organization. 


\section{Suggestions for future Study}

Administrative officers should study on employees' commitment to organization and employees retention.

\section{References}

[1] Chanuntida Prayocharid. (2547). Work performance motivation of personnel at Mahasarakarm Municipality, Thesis, Master of Art, Ratchaphat Mahasarakarm University publisher.

[2] Darika Sriprachan. (2553). Work performance motivation elements of personnel at Naikate Municipality, Kohta District, Lumpang Province, Thesis, Master of Business Administration,

Ratchaphat University publisher.

[3] Ellliot, Andrew J; Covington, Martin. "Approach and Avoidance Motivation". Educational Psychology Review. 13 (2001): 2.

[4] Kansorn Sangsrichan. (2550). Work performance Motivation factors affecting Tambon Bandu Municipality Employees, Chiang Rai Province, Independent Study, Master of Public Policy,

Mae Fah Luang University publisher

[5] Luecha Pakdisri. (2551). Work performance motivation of personnel at Vang Municipality, Ponthong District, Roied Province, Independent Study, Master of Public Policy, Maha Sarakarm University.

[6] Maehr, Martin L; Mayer, Heather (1997). "Understanding Motivation and Schooling: Where We've Been, Where We Are, and Where We Need to go". Educational Psychology Review. 9 (44).

https://doi.org/10.1023/A:1024750807365

[7] Pardee, R. L. (1990). Motivation Theories of Maslow, Herzberg, McGregor \& McClelland. A Literature Review of Selected Theories Dealing with Job Satisfaction and Motivation.

[8] Somtob Salaichai. (2554). Work performance motivation of personnel at Jong Tanon Municipality, Kaochaison districe, Pattalung Province, Thesis, Master of Public Policy, Ratchaphat Somdej Chaophaya University publisher.

[9] Srianan Sridangarm. (2550). Motivation and job completion of Personnel at Pibul Mungsa harn Subdistrict Administrative Organization, Pubul Mangsaharn District, Independent Study, Master of Public Policy, Khonkaen University publisher.

[10] Ugrit Gategunha. (2549). Work motivation of operational personnel at Krung Thai Bank, public Company, Head Quarter Office, Bangkok. 